\title{
ウラニウムの電解定量とナトリウム沈澱分析 濾液より其の回收
}

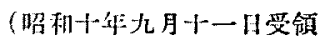

炤和十年十月甘五日印刷)

石橋 雅䉿原开保男

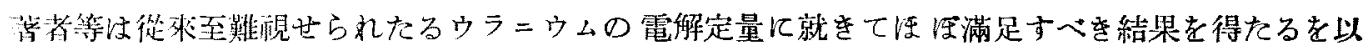

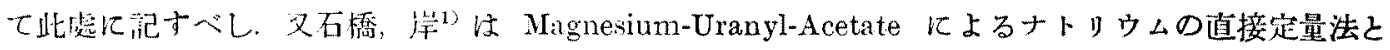
其の應州に關して最近郝告する所ありたるが，この際沈澱 Natrium-Magnesium-Uranyl-Acetate を 忿過せる滤液中に多特のウラニイル踪及びアルコールを含むを以て經游上之等を回收し繰返し使用

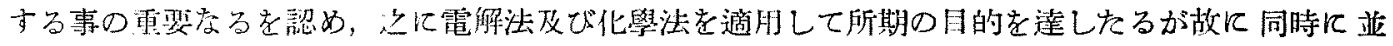

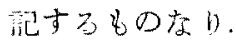

\section{I. ウラニウムの電解定量法}

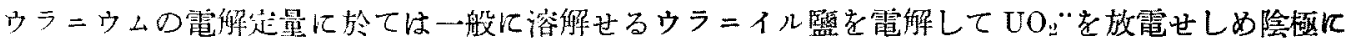
ウラニウムの酸化物として析出せしむるが阽则なり，但しての析出酸化物の陰極への密着力小なる

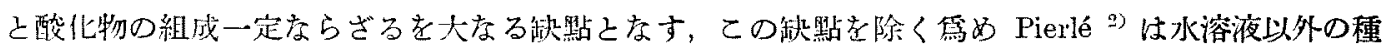

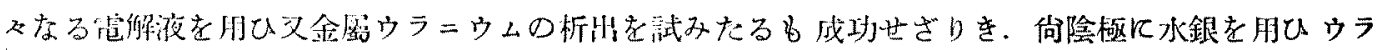
ニウムアマルガムとして迟量せんとする㑝究あれ其失败に終れり.

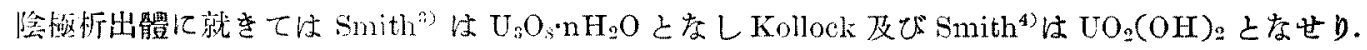

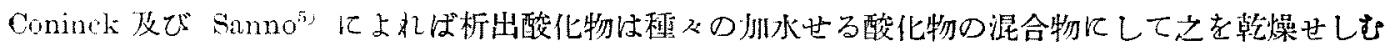

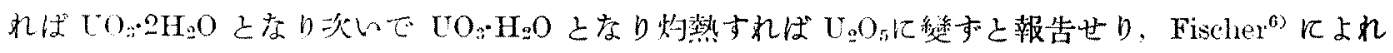

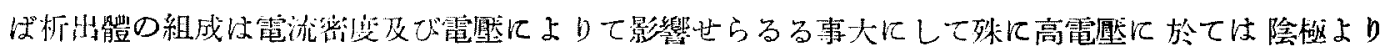

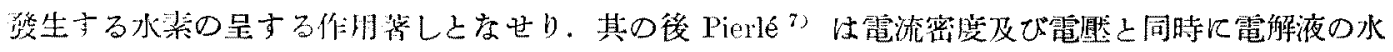
栥イオン泚度如何必析出體に影響する事を述べたり。

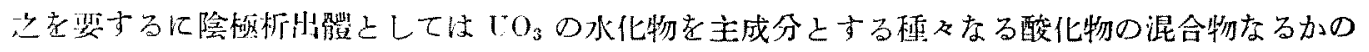

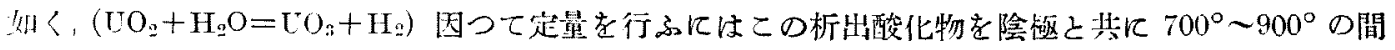

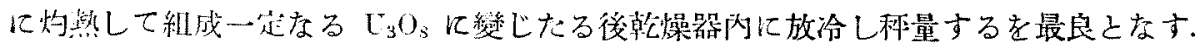

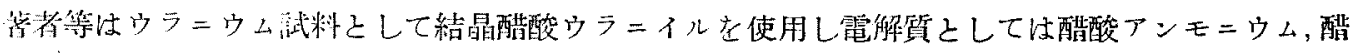

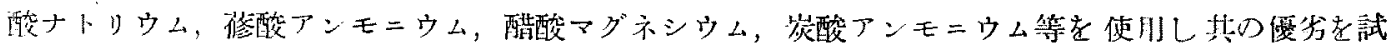

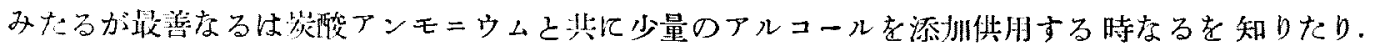

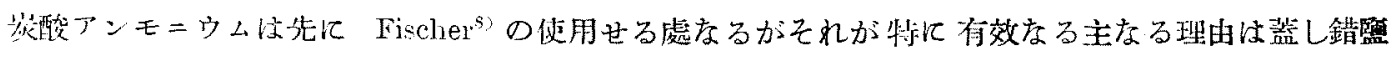
$\left[\mathrm{UO}_{2}\left(\mathrm{CO}_{3}\right)_{3}\right]\left(\mathrm{NH}_{4}\right)_{4}$ 生成の第なるべきか.ナルコールの外に八イドロオキシルアミンも有效なりき.

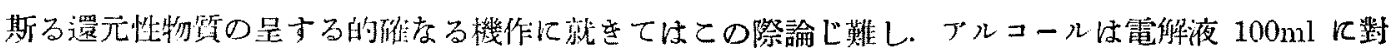
して約 $5 \mathrm{ml}$ が適量にして多量添州は岑酸アンモニウムの析出を來して却て不可なり．

武料は Kahlbaum 製分析用醋酸ウラ

1) 石橋, 崖: 本綕, 56(1935), $35 \%$.

2) C. A. Pierlé: J. Phys. Chem., 28(1919), 517.

3) E. F. Smith: Z. anct. Chem., 19(1880), 18. 4) L. Kollock \& E. F. Smith: J. Am. Chem. Soc:, 23 (1901), 607. 5) O. Coninck \& Sanno: Bull. Acal. Belg., (1901), 321. 195 . 7) C. A. Pierlé: 前为, s) A. Fischer: 前出.

6) A. Fischer: Z. anorg. Chem., 81 (1913), 


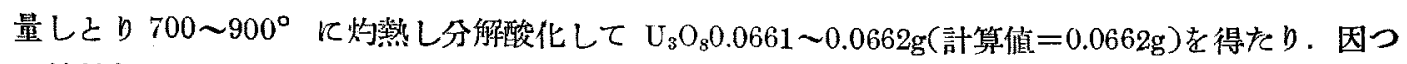
て純䅴なるを證す。

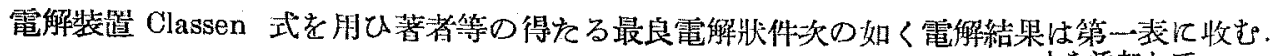

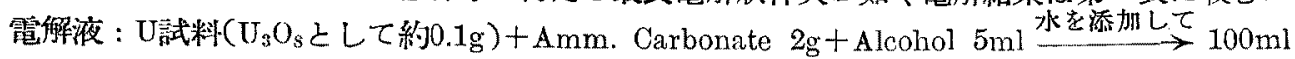

約 6 Volt $, 0.5 \sim 2 A m p ., 60-70^{\circ}, 80^{\circ}$ 以上は析出體の脫落を來す事ありて不可. 陽極赵猼を必らす

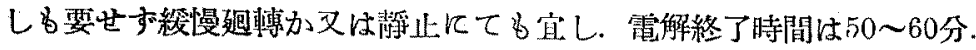

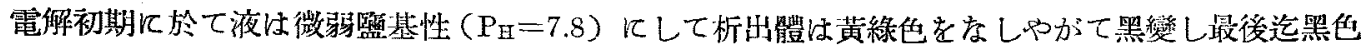
なり。この間液は次第に酸性となり逐に $\mathrm{P}_{\mathrm{B}}=5.4$ 程度に至る。電解液の數滴をとり醋酸を滴下し黄血

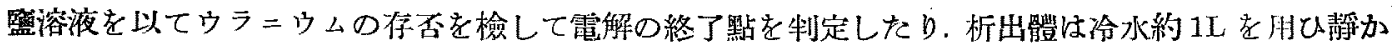

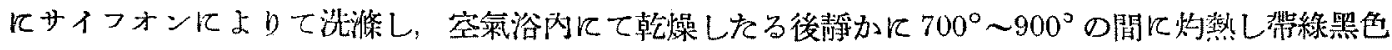

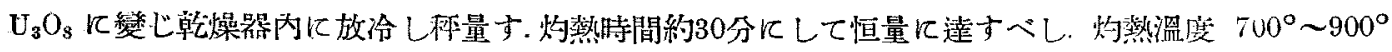

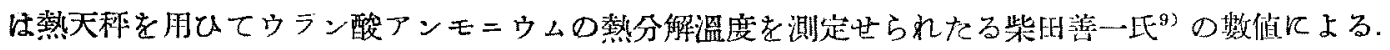

本表實驗數值よりアルコール效用の奶何に顯著なるかを知るへく,アルコール不䏡の㭙大なる(一)

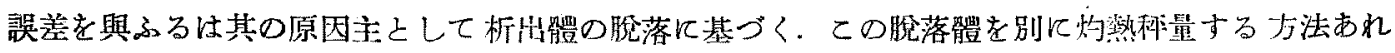
其簡易索缺を且つ正確索るを得亦。

\begin{tabular}{|c|c|c|c|c|c|}
\hline \multirow{2}{*}{ No. } & \multirow{2}{*}{ Alcobol(n]) } & \multicolumn{2}{|c|}{$\mathrm{U}_{3} \mathrm{O}_{8}$} & \multirow{2}{*}{$\frac{\text { 痓 }}{(\mathrm{mg})}$} & 翟 \\
\hline & & 部算㒹 $(\mathrm{g})$ & 蔫驗值 $(\mathrm{g})$ & & $(\%)$ \\
\hline I & - & 0.0995 & 0.0940 & -5.5 & -5.5 \\
\hline 2 & - & 0.0995 & 0.0928 & -6.7 & -6.7 \\
\hline 3 & - & 0.0995 & 0.0986 & -2.9 & -2.9 \\
\hline 4 & - & 0.0988 & 0.0940 & -4.8 & -4.9 \\
\hline 5 & - & 0.0988 & 0.0928 & -6.0 & -6.1 \\
\hline 6 & - & 0.0988 & 0.0966 & -2.2 & -2.2 \\
\hline 7 & 5 & 0.0995 & 0.0998 & +0.3 & +0.3 \\
\hline 8 & 5 & 0.0995 & 0.1002 & +0.7 & +0.6 \\
\hline 9 & 5 & 0.0995 & 0.0999 & +0.4 & +0.4 \\
\hline 10 & $\tilde{5}$ & 0.0995 & 0.0908 & +0.3 & +0.3 \\
\hline 11 & 5 & 0.0995 & 0.1001 & +0.6 & +0.6 \\
\hline 12 & 5 & 0.0971 & 0.0972 & +0.1 & +0.1 \\
\hline 13 & 5 & 0.0971 & 0.0967 & -0.4 & -0.4 \\
\hline 14 & 5 & 0.0971 & 0.0969 & -0.2 & -0.2 \\
\hline
\end{tabular}

\section{II. ウラニウムの回收法}

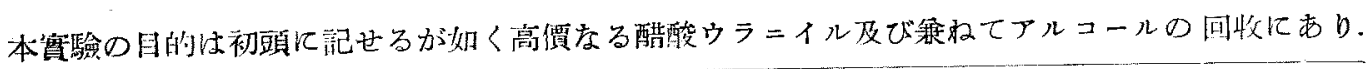

9) 柴明：本誌, $47(1926), 246$. 


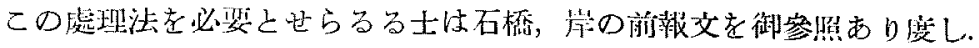

1. 電解法に依る醋酸ウラニイルの回收 ナトリウムを Magnesium-Uranyl-Acetateを以て洮澱

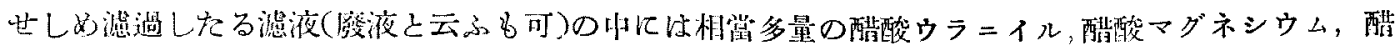

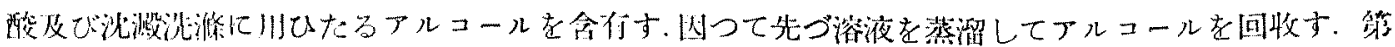
一次然溜アルコール中には自くの小分混在するが故に之を紌化せんには通常行はるるアルコール

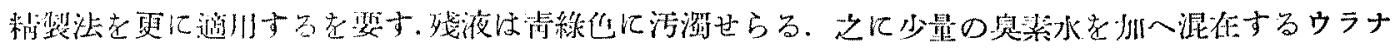

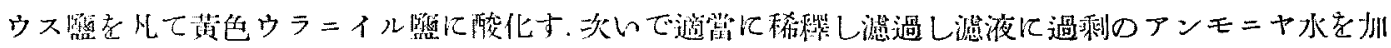

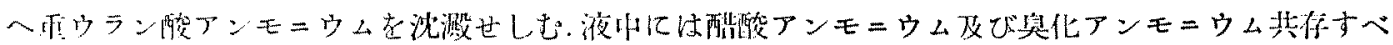

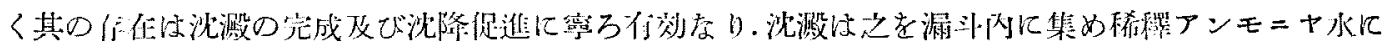

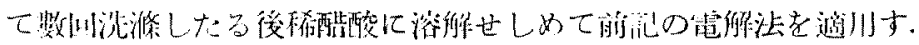

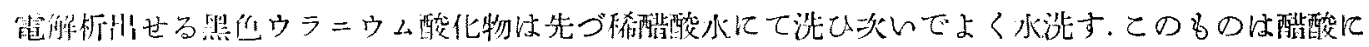
溶解せざるを以てW

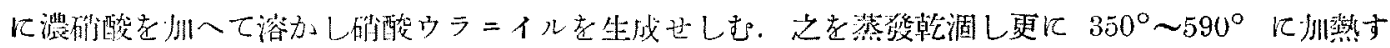

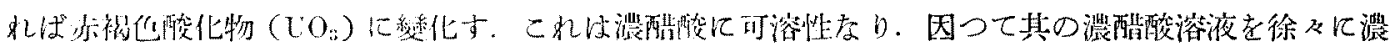

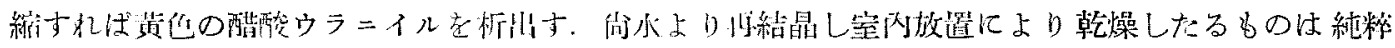

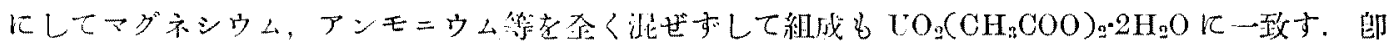

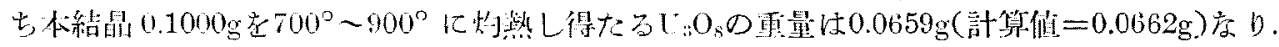

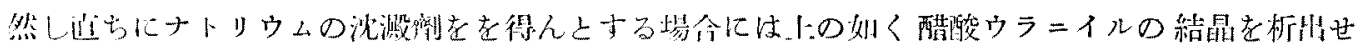

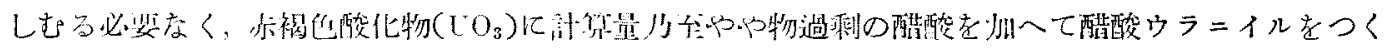

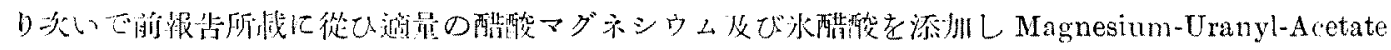

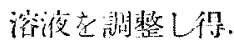

2. 化學的方法による醋酸ウラニイルの回收 ナトリウムを Magnesium-Uranyl-Acetate を以て

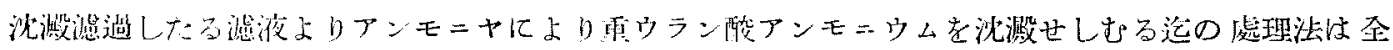

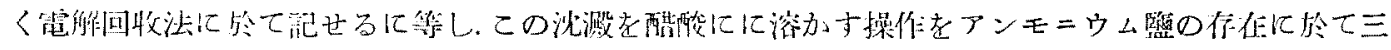

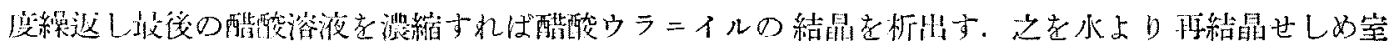

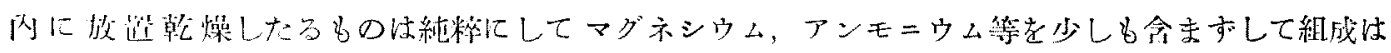

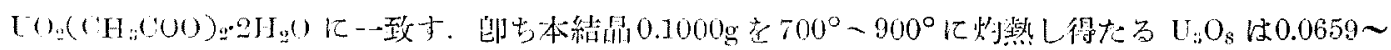
$0.0662 \mathrm{gr}$ (

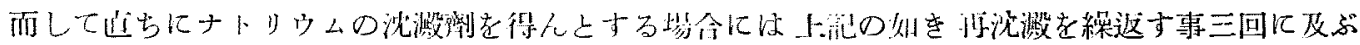

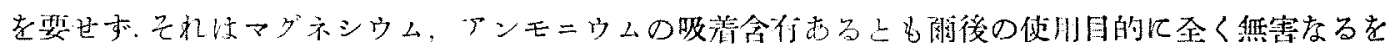
以てなり。

\section{要 旨}

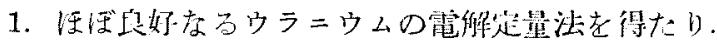

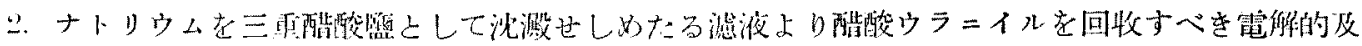
び化學的方法に成功したり。

(宗都策國大学理學部化學教壱)

10) Vanino：無機化學苗唂書 (1913), 610頁. 